\title{
Utility of routine viral load, CD4 cell count, and clinical monitoring among adults with HIV receiving antiretroviral therapy in Uganda: randomised trial
}

Jonathan Mermin director ${ }^{12}$, John P Ekwaru statistician ${ }^{1}$, Willy Were project manager ${ }^{1}$, Richard Degerman data management adviser ${ }^{1}$, Rebecca Bunnell acting director, division of community health ${ }^{13}$, Frank Kaharuza chief, epidemiology branch ${ }^{1}$, Robert Downing director, laboratory services ${ }^{1}$, Alex Coutinho executive director ${ }^{4}$, Peter Solberg project director ${ }^{1}$, Lorraine N Alexander health service officer ${ }^{1}$, Jordan Tappero director, health systems reconstruction office ${ }^{1}$, James Campbell research scientist ${ }^{1}$, David M Moore assistant professor and research scientist ${ }^{256}$

${ }^{1}$ Global AIDS Program, Centers for Disease Control and Prevention (CDC)-Uganda, Entebbe, Uganda; ${ }^{2}$ Division of HIV/AIDS Prevention, National Center for HIV, Viral Hepatitis, STD and TB Prevention CDC, Atlanta, US; ${ }^{3}$ Division of Adult and Community Health, National Center for Chronic Disease Prevention and Health Promotion, CDC, Atlanta; ${ }^{4}$ AIDS Support Organisation, Kampala, Uganda; ${ }^{5}$ British Columbia Centre for Excellence in HIV/AIDS, Vancouver, Canada; ${ }^{6}$ Department of Medicine, Faculty of Medicine, University of British Columbia, Vancouver

\begin{abstract}
Objective To evaluate the use of routine laboratory monitoring in terms of clinical outcomes among patients receiving antiretroviral therapy (ART) in Uganda.

Design Randomised clinical trial

Setting A home based ART programme in rural Uganda.

Participants All participants were people with HIV who were members of the AIDS Support Organisation. Participants had CD4 cell counts $<250$ cells $\times 10^{6} / \mathrm{L}$ or World Health Organization stage 3 or 4 disease.

Interventions Participants were randomised to one of three different monitoring arms: a viral load arm (clinical monitoring, quarterly CD4 counts, and viral load measurements), CD4 arm (clinical monitoring and CD4 counts), or clinical arm (clinical monitoring alone).
\end{abstract}

Main outcome measures Serious morbidity (newly diagnosed AIDS defining illness) and mortality.

Results 1094 participants started ART; median CD4 count at baseline was 129 cells $\times 10^{6} / \mathrm{L}$. Median follow-up was three years. In total, 126 participants died (12\%), 148 (14\%) experienced new AIDS defining illnesses, and 61(6\%) experienced virological failure, defined as two consecutive viral loads $>500$ copies $/ \mathrm{mL}$ occurring more than three months after the start of ART. After adjustment for age, sex, baseline CD4 count, viral load, and body mass index, the rate of new AIDS defining events or death was higher in the clinical arm than the viral load arm (adjusted hazard ratio $1.83, \mathrm{P}=0.002)$ or the CD4 arm (1.49, $\mathrm{P}=0.032)$. There was no significant difference between the CD4 arm and the viral load arm (1.23, $\mathrm{P}=0.31$ ).

Conclusion In patients receiving ART for HIV infection in Uganda, routine laboratory monitoring is associated with improved health and survival compared with clinical monitoring alone.

Trial registration Clinical Trials NCT00119093.

\section{Introduction}

Access to antiretroviral therapy (ART) in Africa increased dramatically over the past decade, beginning with a few thousand people and reaching five million people by mid-2010. ${ }^{1}$ This advance was because of the reduced cost of drugs, increased resources, expanded HIV testing, and activism. Other obstacles continue to limit the number of people taking ART and the ability of health systems to effectively monitor patients, including inadequate number of physicians and allied health staff $^{2}$ and limited laboratory capacity. ${ }^{3}$

In many African countries the annual cost of quarterly CD4 cell counts and measurements of viral load exceeds the cost of generic first line ART. ${ }^{4}$ In addition, establishing sophisticated laboratory services at relatively poorly equipped health facilities remains challenging. Consequently, many people taking ART in Africa receive either no routine laboratory follow-up or infrequent measurements of CD4 cell counts. ${ }^{3}$ When CD4 testing is used as a routine component of care, most programmes offer 
it only once every six or 12 months. ${ }^{56} \mathrm{~A}$ smaller proportion provide routine viral load testing. ${ }^{78}$

High viral load and low CD4 cell count are independently associated with mortality, ${ }^{9-11}$ and changes in viral load and CD4 cell count during treatment have been associated with survival. ${ }^{11}$ Routine monitoring of viral load and CD4 cell counts during ART, however, was adopted in well resourced settings without studies indicating improved survival compared with careful clinical monitoring. One recent mathematical model showed little benefit and considerable cost even during 20 years of follow-up. ${ }^{12}$ Furthermore, programmes in Haiti ${ }^{13}$ and Malawi ${ }^{14}$ have reported treatment success with clinical monitoring alone, although no groups with laboratory monitoring were available for comparison. By reducing or eliminating frequent laboratory monitoring, there is potential for increasing the number of people who could be treated. Reduced laboratory monitoring, however, might also lead to premature or delayed changes to second line treatment, more antiretroviral resistance, or increased morbidity. Changes in CD 4 cell counts do not accurately predict suppression of viral load. ${ }^{15-17}$ A recently reported randomised clinical trial examining different monitoring strategies for individuals receiving ART found only marginal clinical benefits in terms of mortality associated with providing six monthly monitoring of CD4 cell count in addition to clinical monitoring in Uganda and Zimbabwe. ${ }^{18}$ Furthermore, the authors concluded that the addition of monitoring CD4 cell counts was not cost effective according to current WHO guidelines.

WHO guidelines provide flexible recommendations for monitoring people taking ART. ${ }^{19}$ We initiated a randomised clinical trial in Uganda to empirically evaluate whether routine monitoring of viral loads and CD4 cell count provides clinical benefits to individuals receiving ART in sub-Saharan Africa.

\section{Methods \\ Study design}

Beginning in May 2003, after receiving written informed consent we assessed adults aged $\geq 18$ with HIV-1 who were clients of the Tororo Branch of the AIDS Support Organization (TASO) for eligibility for study enrolment. Enrolment was offered to clients with a CD 4 cell count $<250$ cells $\times 10^{6} / \mathrm{L}$ or severe HIV disease (defined as WHO stage 3 or 4 or a history of recurrent herpes zoster), a serum aspartate aminotransferase (AST) or alanine aminotransferase (ALT) activity less than five times the upper limit of normal, a calculated creatinine clearance $\geq 0.42$ $\mathrm{mL} / \mathrm{s}$, and a Karnofsky score of $>40 \%$; isolated pulmonary tuberculosis alone was not an inclusion criterion because in Africa it is common among people with HIV even without immunocompromise. Participants who had taken ART previously were enrolled in the study, but unless use consisted only of nevirapine for prevention of mother to child transmission they were excluded from analyses.

Investigators used a random number generator and blocked randomisation to assign participants to one of three different monitoring regimens: the "viral load arm," with quarterly HIV viral loads and CD4 cell counts and weekly home visits by a trained lay person using a standardised symptom questionnaire; the "CD4 arm," with quarterly CD4 cell counts and weekly home visits; or the "clinical arm," with weekly visits alone. All participants had measurements of viral load and CD4 cell count performed on quarterly blood samples. Results of these were made available to study physicians as appropriate to the participants' assignment arm. All participants underwent a CD4 cell count at study enrolment to determine eligibility for ART. Follow-up continued until 4 February 2007.
The first line ART regimen was stavudine, lamivudine, and nevirapine (or efavirenz for those taking concurrent rifampicin). Trained lay field officers visited clients' homes weekly to deliver drugs and collect data regarding drug adherence, potential symptoms of drug toxicity, or death of a household member in the preceding seven days. ${ }^{20}$ Prepackaged drugs were replaced by using a weekly storage container, and pill counts were conducted at the study clinic by a pharmacist. Participants were weighed each month during home visits and these weights and body mass index (BMI) scores were provided to clinicians. After enrolment, no routine clinic visits were scheduled but participants were encouraged to come to the clinic or hospital if they were ill and were transported to the clinic for assessment if they had specifically defined symptoms or severe illness during a home visit.

Cryptococcal disease was diagnosed by compatible symptoms and serum cryptococcal antigen testing (Crypto-LA, Wampole Laboratories, Cranberry, NJ). Pulmonary tuberculosis was defined as positive results for acid fast bacilli during microscopy from two sputum smears or negative results from sputum smears but with chest radiography compatible with tuberculosis and a lack of response to a two week trial of antibiotics.

Extrapulmonary tuberculosis was diagnosed by clinical presentation and occasionally by lymph node biopsy and pathological confirmation. Diagnoses of Kaposi's sarcoma and cervical cancer were based on biopsy results. Pneumocystis jirovecii pneumonia was diagnosed clinically with chest radiography, clinical presentation, and a response to cotrimoxazole treatment. Monitoring and diagnostic procedures for the occurrence of illness did not differ between study arms. Physicians responsible for patients in the two study arms that included routine viral loads or CD4 counts, or both, received these results on a quarterly basis.

Participants continued with daily cotrimoxazole prophylaxis regardless of CD4 cell count. Participants who met clinical or laboratory definitions of failure of ART were generally switched to didanosine, tenofovir, and lopinavir/ritonavir.

In the viral load arm, treatment failure was defined as two consecutive viral load measurements $>500$ copies/mL occurring more than six months after the start of ART. For the CD4 monitoring arm, persistently declining CD4 cell counts on two consecutive measurements was considered to indicate treatment failure. For the clinical arm, predefined primary indications for treatment change included determination of a new or recurrent CDC category $\mathrm{C}$ condition after three months of ART, documented unintentional weight loss of $\geq 10 \%$, constitutional symptoms such as fever $\left(>38.5^{\circ} \mathrm{C}\right)$ or diarrhoea lasting more than a month without a correctable cause, or new oral or recurrent vaginal candidiasis. Pulmonary tuberculosis itself was not an indication for failure. The first response to a worsening trend in CD4 or viral load was counselling about adherence to treatment. Supplemental CD4 and viral load assessments could be ordered during clinic visits. Study physicians, nurses, counsellors, and other staff met weekly in a case conference and discussed all deaths, opportunistic illnesses, and abnormal laboratory results and approved all regimen changes.

\section{Laboratory procedures}

Plasma samples were screened for HIV infection by two enzyme linked immunoassays (EIA) in parallel (Recombigen HIV-1/HIV-2, Trinity Biotech, Dublin; and Murex HIV1.2.0, Abbott diagnostics, Chicago, IL). Specimens concordantly positive or negative received no further testing. Specimens with discordant results were retested with the same algorithm and, 
if still discordant, by western blotting (LAV Blot, Biorad, Richmond, VA). HIV viral loads were measured with Cobas Amplicor HIV-1 Monitor version 1.5 ultrasensitive assay (Roche, Branchburg, NJ) for baseline measurements, which had a lower limit of detection of 400 copies/mL. Follow-up viral load measurements were conducted with the Cobas Taqman (manual extraction) assay, with a lower limit of detection of 50 copies/mL. CD4 cell counts were done with TriTEST reagents following an in house dual platform protocol and MultiSET and Attractors software with a FACScan or FACSCalibur flow cytometer (Becton-Dickinson, Franklin Lakes, NJ). Complete blood counts were provided with CD4 cell counts.

\section{Data analysis}

The main outcome was a composite of severe AIDS associated morbidity and mortality (referred to as severe morbidity and mortality). This included death from any cause, all US Centers for Disease Control category C illnesses except pulmonary tuberculosis, and four additional category B illnesses: more than one episode of herpes zoster or in multiple dermatomes, recurrent severe bacterial infections, peripheral neuropathy not associated with drug toxicity, or oral hairy leucoplakia. We planned to enrol a minimum of 333 participants in each monitoring arm. With $80 \%$ power and a two sided test at a median follow-up of three years, this sample size should allow us to detect an absolute difference of $8 \%$ between the proportion of participants with a serious morbidity or who died in the clinical arm and the viral load arm if the proportion in the viral load arm was $12 \%$. Data were entered with Epi Info (CDC, Atlanta, GA) and analysed with SAS 9.0 (SAS Institute, Cary, $\mathrm{NC})$.

For the primary analysis, we used an intention to treat approach including all randomised participants. We also performed per protocol analyses that included only participants who received ART for at least 90 days as the different monitoring regimens would not theoretically affect outcomes until the time of the first blood sample. We developed Kaplan-Meier survival curves to compare outcomes and used multivariable Cox regression models to adjust for possible associations with morbidity and mortality, with a backward stepwise approach. Hazard ratios and incidence rate ratios were adjusted for age, sex, and baseline CD4 cell count, viral load, and BMI, unless otherwise specified. A P value $<0.05$ was considered significant. We assessed the proportionality assumption of time dependent covariates - that is, interaction between monitoring arms and time, and over- and under- dispersion of data. For analyses of the incidence of illnesses, we used a Poisson regression model with a log link function. Person time for people lost to follow-up or transferred to a different provider was censored at the time of the last home visit at which they received ART. We estimated adherence by calculating a weekly drug possession ratio that incorporated an individual's pill count data and any lapses in delivery that could have occurred because of drug holidays or being away from home.

A data safety monitoring board reviewed data every three months and was asked to reject the null hypothesis of monitoring arm equivalence if the rate of severe morbidity and mortality in any arm exceeded another by three standard errors of the difference ("Haybittle-Peto" rule). ${ }^{21}$

\section{Results}

Of 1956 adults evaluated for enrolment, 1160 (59\%) were eligible for ART and randomised to one of the three arms. Of these, 44 (4\%) were excluded from analysis because they had previously received ART, leaving 368 in the viral load arm, 371 in the CD4 arm, and 377 in the clinical arm (fig $1 \Downarrow$ ). The median age was 38 (interquartile range 32-44); 73\% were women; and the median baseline CD4 cell count was 129 cells $\times 10^{6} / \mathrm{L}$ (64-195). Demographic and clinical parameters were similar across study arms, except that fewer women were enrolled in the clinical arm (table $1 \Downarrow$ ).

After inclusion in the study, 360 participants in the viral load arm, 364 in the CD4 arm, and 370 in the clinical arm started ART. Median follow-up was three years (interquartile range 2.9-3.2) and was similar across arms. The median time from the first CD4 cell count to initiation of ART was 28 days (22-37). Table $2 \Downarrow$ shows the time to first event analysis, with an intention to treat approach from the time of initiation of ART. Forty seven individuals experienced at least one serious morbidity or died in the viral load arm, 58 in the CD4 arm, and 72 in the clinical arm (table $2 \Downarrow$ ). In a Cox proportional hazards model with adjustment for baseline age, sex, CD4 cell count, viral load, and BMI, participants in the clinical arm were more likely to have at least one episode of serious morbidity or die compared with participants in the viral load arm (7.6 $v 4.8$ per 100 person years; adjusted hazard ratio $1.83,95 \%$ confidence interval 1.25 to 2.69$)$ and the CD4 arm (7.6 $v 6.0$ per 100 person years; $1.49,1.03$ to 2.13 ). There was no significant difference in the risk of first serious morbidity or death between the CD4 arm and the viral load arm (1.23, 0.82 to 1.84$)$; we had $80 \%$ power to detect a hazard ratio as small as 1.75 at $\mathrm{P}<0.05$.

Figures 2 and 3 show different analyses of time to first event of severe morbidity or mortality. $\Downarrow \Downarrow$ The per protocol analysis comparing events after the first 90 days after initiation of ART included similar proportions of participants per arm (349/368 (95\%) for the viral load arm, 346/371 (93\%) for the CD4 arm, and 352/377 (93\%) for the clinical arm; $\mathrm{P}=0.61$ ) (fig 3) and found comparable results with the intention to treat analysis (table 2 and fig 2[f]).

With an intention to treat approach, several CDC category $\mathrm{C}$ illnesses were more common among people in the clinical arm than in the viral load arm: extrapulmonary tuberculosis $(1.4 v$ 0.3 events per 100 person years; incidence rate ratio $7.27,1.64$ to 32.30$)$; cryptococcal disease $(2.2 v 1.1 ; 2.21,1.06$ to 4.59$)$; and $P$ jiroveci pneumonia $(1.1 v 0.2 ; 9.57,1.96$ to 46.71$)$ (table $3 \Downarrow)$. Similar results were seen when we compared the clinical arm with the CD4 arm (table 3 ) and using a per protocol analysis (data not shown). There were no significant differences between the CD4 and viral load arms.

\section{Mortality}

With an intention to treat approach from the time of ART randomisation, $126(11 \%)$ participants died: 37 in the viral load arm, 40 in the CD4 arm, and 49 in the clinical arm (table $2 \Downarrow$ ); $60 / 126(48 \%)$ deaths occurred in the first three months. Participants in the clinical arm were more likely to die than those in the viral load arm ( $4.9 v 3.7$ per 100 person years; adjusted hazard ratio $1.57,1.00$ to 2.46$)$ and those in the CD4 arm (4.9 $v 4.0$ per 100 person years; $1.43,0.92$ to 2.21$)$. There was no significant difference in mortality between the CD4 and viral load arms (1.10. 0.69 to 1.75). In the per protocol analysis, there were similar but non-significant trends (table $2 \Downarrow$ ).

\section{Viral load and CD4 cell count response}

At baseline, the median viral load was 216000 copies $/ \mathrm{mL}$ (interquartile range 72 000-536 000). During follow-up, 61 (5.5\%) participants had viral load measurements $>500$ copies $/ \mathrm{mL}$ on two consecutive occasions; 16 (4.6\%) in the viral load arm, 
$26(7.5 \%)$ in the CD4 arm, and $19(5.4 \%)$ in the clinical arm $(\mathrm{P}=0.56)$. Of 1047 participants in the per protocol analysis, 28 $(2.8 \%)$ were changed to a regimen containing a protease inhibitor (table $4 \Downarrow$ ). Of the 61 participants with virological failure, 13 were switched to second line regimens: seven (44\%) of 16 in the viral load arm, four $(15 \%)$ of 26 participants in the CD4 arm, and two (11\%) of 19 in the clinical arm. All participants who were changed to second line treatment in the viral load and CD4 arms had at least two consecutive viral loads $>500$ copies/mL; only two (12\%) of 17 patients in the clinical arm who were switched to second line had two consecutive viral loads $>500$ copies $/ \mathrm{mL}$. Of these 17 patients, all were switched more than a year after they started ART because of AIDS defining events: six had cryptococcal disease, five had Kaposi's sarcoma; one had extrapulmonary tuberculosis, two had $>10 \%$ unintentional weight loss, one had cervical cancer; one had cytomegalovirus infection, and one had recurrent pneumonia. Eight $(47 \%)$ participants changed in the clinical arm had CD4 cell counts $<200$ cells $\times 10^{6} / \mathrm{L}$ at the time of their illness.

Among participants with virological failure who were not switched to second line therapy the median viral load six months later was greater for those in the clinical arm (7340 copies $/ \mathrm{mL}$, interquartile range 2315-10 350) compared with $<50$ copies $/ \mathrm{mL}$ $(<50-<50)(\mathrm{P}=0.002)$ in the viral load arm and 1340 copies $/ \mathrm{mL}$ $(<50-9540)(\mathrm{P}=0.012)$ in the $\mathrm{CD} 4 \mathrm{arm}$. Among the 17 people in the clinical arm with virological failure who were not switched to second line treament, however, only two deaths and no opportunistic infections occurred. For participants in the clinical arm, the mean medication possession ratio was worse in the three months after viral load failure compared with the three months before $(94.1 \% v 98.5 \%$ of pills taken; mean pairwise difference $4.5 \%, 0.4 \%$ to $8.5 \% ; \mathrm{P}=0.032$ ) but it was not significantly different for the CD4 arm $(99.1 \% v 98.6 \%$; $-0.5 \%,-2.3 \%$ to $1.3 \% ; \mathrm{P}=0.57)$ or the viral load arm $(92.1 \%$ $v 100 \% ; 7.9 \%,-4.2 \%$ to $20.1 \%$; $\mathrm{P}=0.17$ ).

\section{Discussion}

The addition of quarterly monitoring of CD4 cell count among adults taking ART in Uganda was associated with better clinical outcomes than clinical monitoring alone. Similar results were seen for the combined end point of new AIDS defining illness or mortality as well as specific opportunistic illnesses, such as Cryptococcus infection and tuberculosis.

These results provide reassurance to clinicians and patients in resource limited settings who have access to CD4 cell counts but not viral load testing. Most people taking ART in Africa, however, receive limited laboratory monitoring. ${ }^{322}$ Although the benefits associated with laboratory testing were relatively small compared with the effectiveness of ART in reducing mortality, ${ }^{18}{ }^{23}$ they were present, and support the continued expansion of monitoring CD4 cell counts as well as ART.

Several studies have concluded that clinical indicators and changes in CD4 cell count are not good predictors of virological failure. ${ }^{17}{ }^{24-26}$ In our study, however, people in the CD4 cell count monitoring arm did better than those with clinical monitoring alone. This could be because CD4 cell counts identified issues related to poor adherence before major clinical events occurred. Most people in the clinical monitoring arm with virological failure had detectable virus and worsening adherence three to six months later. In addition, CD4 cell count predicts risk for clinical events, even with undetectable virus. ${ }^{27-29}$

Following current practice, we did not switch regimens in the viral load monitoring arm if people had a poor immunological response or new AIDS defining event if they also had undetectable virus. In the CD4 arm, we changed people if they had a poor immunological response. All of those individuals switched, however, had detectable viral load, indicating a reasonable concordance between $\mathrm{CD} 4$ and viral load monitoring. In the clinical arm, however, $88 \%$ of people switched to second line treatment because of the diagnosis of an AIDS defining illness had undetectable viral load. Because second line regimens are expensive and there are limited options for third line treatment in most resource limited settings, use of clinical monitoring could have additional long term drawbacks.

Routine monitoring of viral load should reduce the amount of time that patients take a failing regimen and therefore potentially reduce clinical events, decrease the frequency of antiretroviral drug mutations, and improve efficacy of second line regimens. ${ }^{17}$ We did not find that quarterly viral loads provided additional clinical benefit to patients. This could have been because of limited statistical power in our study. The rates of virological failure in our study ( $6 \%$ among survivors with a median of three years of follow-up) are generally lower than most reported programmes from the region, as surveyed in a recent systematic review. ${ }^{30}$ That review included five reports with follow-up times of 36 months or more and the proportion of participants with virological success varied from $58 \%$ to $98 \%$. Our study had excellent adherence, probably because of the home based design and frequent drug delivery, and a more typical setting might have seen more drug failure and a higher incidence of morbidity and mortality. Designing programmes that maximise retention of patients and support adherence to treatment $\mathrm{t}^{22}{ }^{31-33}$ might be more important than the use of laboratory monitoring, and many programmes in Africa have had default rates of $20 \%$ or more, ${ }^{34}$ suggesting potential for improvement.

It is also possible that CD4 cell counts identified people with virologically defined treatment failure or because monitoring CD4 cell counts detected correctable problems with adherence to ART. In addition, all participants switched to second line treatment in the CD4 cell count monitoring arm had detectable viral load, and those in the CD4 arm with virological failure who were not switched mostly had low or undetectable viral load six months later. Partial ${ }^{35}$ or intermittent ${ }^{36}$ virological suppression has been associated with better outcomes than no change, and even dual ART has positive immunological, virological, and survival effects. ${ }^{37}$

It is not clear whether longer term follow-up would show benefits to viral load testing. An evaluation with data from resource limited countries found no evidence of improved mortality in programmes with viral load testing, ${ }^{38}$ but follow-up was relatively short. In addition, modelling of different data showed little long term benefit of either viral load or CD4 cell count monitoring. ${ }^{12}$ Resistance to lamivudine and nevirapine is already present in $90 \%$ of patients by the time of virological failure, ${ }^{39}{ }^{40}$ but the rate of development of thymidine analogue mutations is variable. ${ }^{22} 4142 \mathrm{We}$ switched only a few people to second line regimens and therefore could not assess whether people who had a longer time with detectable virus before switching would do less well on second line regimens.

\section{Comparison with other studies}

Our results are largely consistent with those of the Development of Antiretroviral Therapy for Africa (DART) trial, which was recently completed in two sites in Uganda and one in Zimbabwe, ${ }^{18}$ although we differ somewhat in our interpretation of these results. Participants in DART were randomised to clinical monitoring alone or clinical monitoring plus six monthly monitoring of $\mathrm{CD} 4$ cell count. After five years of follow-up, 
survival was $87 \%$ (95\% confidence interval $85 \%$ to $88 \%$ ) in the clinical monitoring arm and $90 \%$ (88\% to $91 \%$ ) in the clinical plus CD4 cell count monitoring arm. Neither group received routine viral load testing. While the authors concluded that these differences were quite small and probably did not justify the added expense of $\mathrm{CD} 4$ cell count testing, they were unable to show that clinical monitoring was not inferior to CD4 cell count monitoring. Our associated formal cost effectiveness analysis of our study further informs the debate regarding appropriate resource allocation for ART programmes in this region. ${ }^{43}$

\section{Strengths and weaknesses}

In this randomised trial we examined the efficacy of both routine CD4 cell count and viral load monitoring on clinical outcomes in a resource limited setting. The study does have some limitations. Although participants were randomised at baseline, there were more men in the clinical arm, and at least one study has found that men have worse clinical outcomes during ART than women, although this was mostly because of more advanced immunodeficiency and worse adherence to treatment. ${ }^{44}$ To account for this potential issue, we adjusted for sex in all models. The virological criteria for switching were conservative in relation to switching criteria in industrialised countries, ${ }^{45}$ although more liberal than current WHO recommendations, ${ }^{19}$ and could have led to underestimation of the effectiveness of viral load monitoring in improving clinical outcomes. Also, because we had few participants with virological failure, we had limited statistical power to examine the effectiveness of viral load testing. Lastly, although diagnostic procedures for opportunistic infections were identical across arms, clinicians could not be blinded, and they might have more intensively examined participants in the clinical arm for illness. Some of the illnesses had clear laboratory or pathological diagnoses, such as cryptococcal disease and Kaposi's sarcoma, and there was increased mortality in the clinical arm that would not be susceptible to ascertainment bias.

\section{Conclusions and policy implications}

The number of people estimated to be acquiring new HIV infections in the world each year exceeds the number currently taking ART. ${ }^{46}$ As we expand programmes to meet the current and future need for ART, efforts should be made to increase access to CD4 cell counts not only for determining eligibility for ART but also for monitoring people already receiving ART.

We thank Tororo Hospital staff; the staff and clients of the AIDS Support Organisation; the US Embassy in Kampala; Global AIDS Program headquarters; and staff of CDC-Uganda, especially the informatics, clinical, laboratory, and administrative units of CDC-Tororo. We also thank Barbara Marston for helpful comments on the manuscript.

Contributors: DMM, RB, AC, PS, JC, JT, and JM were principal investigators during the study and were involved in writing protocols and/or supervising study implementation, interpreting data, and editing the manuscript. JM is the main author. WW supervised study implementation. JPE and RD performed statistical analyses. FK supported study development, coordination, and data interpretation. RD supervised laboratory testing. LNA acted as the study coordinator and $A C$ helped to design and implement the study and ensured the protocol was applicable to TASO. JM is guarantor.

Funding: This study was funded by the US Centers for Disease Control and Prevention, the US Agency for International Development, and the President's Emergency Plan for AIDS Relief. US Centers for Disease Control and Prevention staff and other investigators were involved in the study design and implementation, data analysis, and writing of thepaper. The findings and conclusions are those of the authors and do not necessarily represent the views of the Centers for Disease Control and Prevention

Competing interests: All authors have completed the ICMJE uniform disclosure form at www.icmje.org/coi_disclosure.pdf (available on request from the corresponding author) and declare: JM, JPE, WW, $\mathrm{RD}, \mathrm{RB}, \mathrm{FK}, \mathrm{RD}, \mathrm{PS}$, LNA, JT, DMM had support from the US Center for Disease Control for the submitted work. AC received no direct support for this study; DMM also received support from the Canadian Institutes for Health Research through a New Investigator Award; no financial relationships with any organisations that might have an interest in the submitted work in the previous three years; no other relationships or activities that could appear to have influenced the submitted work.

Ethical approval: The studies were approved by the Institutional Review Boards of the Centers for Disease Control and Prevention and the Uganda Virus Research Institute and informed consent was given by all patients.

Data sharing: Technical appendix, statistical code, and dataset available from the corresponding author. Presented data are anonymised and risk of identification is low.

UNAIDS. Report on the global AIDS epidemic 2010. UNAIDS, 2010.

2 Samb B, Celletti F, Holloway J, Van Damme W, De Cock KM, Dybul M. Rapid expansion of the health workforce in response to the HIV epidemic. N Engl J Med 2007;357:2510-4. 3 Koenig SP, Kuritzkes DR, Hirsch MS, Leandre F, Mukherjee JS, Farmer PE, et al. Monitoring HIV treatment in developing countries. BMJ 2006;332:602-4.

4 Kumarasamy N. Generic antiretroviral drugs-will they be the answer to HIV in the developing world? Lancet 2004;364:3-4.

5 Chang LW, Alamo S, Guma S, Christopher J, Suntoke T, Omasete R, et al. Two-year virologic outcomes of an alternative AIDS care model: evaluation of a peer health worker and nurse-staffed community-based program in Uganda. J Acquir Immune Defic Syndr 2009;50:276-82.

6 Hosseinipour MC, van Oosterhout JJ, Weigel R, Phiri S, Kamwendo D, Parkin N, et al. The public health approach to identify antiretroviral therapy failure: high-level nucleoside reverse transcriptase inhibitor resistance among Malawians failing first-line antiretroviral therapy. AIDS 2009;23:1127-34.

7 Keiser O, Anastos K, Schechter M, Balestre E, Myer L, Boulle A, et al. Antiretroviral therapy in resource-limited settings 1996 to 2006: patient characteristics, treatment regimens and monitoring in sub-Saharan Africa, Asia and Latin America. Trop Med Int Health Jul 2008;13:870-9.

8 Kamya MR, Mayanja-Kizza H, Kambugu A, Bakeera-Kitaka S, Semitala F, Mwebaze-Songa $P$, et al. Predictors of long-term viral failure among Ugandan children and adults treated with antiretroviral therapy. J Acquir Immune Defic Syndr 2007;46:187-93.

9 Antiretroviral Therapy Cohort Collaboration. Life expectancy of individuals on combination antiretroviral therapy in high-income countries: a collaborative analysis of 14 cohort studies. Lancet 2008;372:293-9.

10 Egger M, May M, Chene G, Phillips AN, Ledergerber B, Dabis F, et al. Prognosis of HIV-1-infected patients starting highly active antiretroviral therapy: a collaborative analysis of prospective studies. Lancet 2002;360:119-29.

11 Lundgren JD, Babiker A, El-Sadr W, Emery S, Grund B, Neaton JD, et al. Inferior clinical outcome of the $\mathrm{CD} 4+$ cell count-guided antiretroviral treatment interruption strategy in the SMART study: role of CD4+ cell counts and HIV RNA levels during follow-up. J Infect Dis 2008:197:1145-55.

12 Phillips AN, Pillay D, Miners AH, Bennett DE, Gilks CF, Lundgren JD. Outcomes from monitoring of patients on antiretroviral therapy in resource-limited settings with viral load, CD4 cell count, or clinical observation alone: a computer simulation model. Lancet 2008;371:1443-51

13 Koenig SP, Leandre F, Farmer PE. Scaling-up HIV treatment programmes in resource-limited settings: the rural Haiti experience. AIDS 2004:18(suppl 3):S21-25.

14 Harries AD, Schouten EJ, Libamba E. Scaling up antiretroviral treatment in resource-poor settings. Lancet 2006;367:1870-2.

15 Moore D, Awor A, Downing R, Were W, Behumbiize P, Mermin J. Evaluation of immunologic monitoring to identify patients with virologic failure after initiation of antiretroviral therapy in rural Uganda. Paper presented at: XVI International AIDS Conference, 2006; Toronto, Canada.

16 Reynolds SJ, Nakigozi G, Newell K, Ndyanabo A, Galiwongo R, Boaz I, et al. Failure of immunologic criteria to appropriately identify antiretroviral treatment failure in Uganda. AIDS 2009;23:697-700.

17 Calmy A, Ford N, Hirschel B, Reynolds SJ, Lynen L, Goemaere E, et al. HIV viral load monitoring in resource-limited regions: optional or necessary? Clin Infect Dis 2007:44:128-34

18 Mugyenyi P, Walker AS, Hakim J, Munderi P, Gibb DM, Kityo C, et al. Routine versus clinically driven laboratory monitoring of HIV antiretroviral therapy in Africa (DART): a randomised non-inferiority trial. Lancet 2010;375:123-31.

19 World Health Organization. Antiretroviral therapy for HIV infection in adults and adolescents in resource-limited settings: recommendations towards a public health approach. WHO, 2010.

20 Weidle PJ, Wamai N, Solberg P, Liechty C, Sendagala S, Were W, et al. Adherence to antiretroviral therapy in a home-based AIDS care programme in rural Uganda. Lancet 2006;368:1587-94.

21 Lai TL, Shih MC, Zhu G. Modified Haybittle-Peto group sequential designs for testing superiority and non-inferiority hypotheses in clinical trials. Stat Med 2006;25:1149-67.

22 Ferradini L, Jeannin A, Pinoges L, Izopet J, Odhiambo D, Mankhambo L, et al. Scaling up of highly active antiretroviral therapy in a rural district of Malawi: an effectiveness assessment. Lancet 2006;367:1335-42. 


\section{What is already known on this topic}

The addition of viral load testing or CD4 cell count testing, or both, might or might not improve clinical outcomes among people receiving ART in resource limited settings

One randomised study showed that the addition of monitoring $\mathrm{CD} 4$ cell counts resulted in improved survival among people receiving ART in Uganda and Zimbabwe

\section{What this study adds}

There is an increased risk of new AIDS defining illnesses and death among people receiving ART without any laboratory monitoring There are no significant differences in clinical outcomes between those patients who received quarterly CD4 cell counts and those who received quarterly CD4 cell counts and viral load measurements

23 Mermin J, Were W, Ekwaru JP, Moore D, Downing R, Behumbiize P, et al. Mortality in HIV-infected Ugandan adults receiving antiretroviral treatment and survival of their HIV-uninfected children: a prospective cohort study. Lancet 2008;371:752-9.

24 Bagchi S, Kempf MC, Westfall AO, Maherya A, Willig J, Saag MS. Can routine clinical markers be used longitudinally to monitor antiretroviral therapy success in resource-limited settings? Clin Infect Dis 2007:44:135-8.

25 Bisson GP, Gross R, Strom JB, Rollins C, Bellamy S, Weinstein R, et al. Diagnostic accuracy of CD4 cell count increase for virologic response after initiating highly active antiretroviral therapy. AIDS 2006;20:1613-9.

26 Moore DM, Mermin J, Awor A, Yip B, Hogg RS, Montaner JS. Performance of immunologic responses in predicting viral load suppression: implications for monitoring patients in resource-limited settings. J Acquir Immune Defic Syndr 2006;43:436-9.

27 Moore DM, Hogg RS, Yip B, Wood E, Tyndall M, Braitstein P, et al. Discordant immunologic and virologic responses to highly active antiretroviral therapy are associated with increased mortality and poor adherence to therapy. J Acquir Immune Defic Syndr 2005;40:288-93.

28 Nicastri E, Chiesi A, Angeletti C, Sarmati L, Palmisano L, Geraci A, et al. Clinical outcome after 4 years follow-up of HIV-seropositive subjects with incomplete virologic or immunologic response to HAART. J Med Virol 2005;76:153-60.

29 Tuboi SH, Brinkhof MW, Egger M, Stone RA, Braitstein P, Nash D, et al. Discordant responses to potent antiretroviral treatment in previously naive HIV-1-infected adults initiating treatment in resource-constrained countries: the antiretroviral therapy in low-income countries (ART-LINC) collaboration. J Acquir Immune Defic Syndr 2007:45:52-9.

30 Barth RE, van der Loeff MF, Schuurman R, Hoepelman AI, Wensing AM. Virological follow-up of adult patients in antiretroviral treatment programmes in sub-Saharan Africa: a systematic review. Lancet Infect Dis 2010;10:155-66.

31 Bedelu M, Ford N, Hilderbrand K, Reuter $\mathrm{H}$. Implementing antiretroviral therapy in rural communities: the Lusikisiki model of decentralized HIV/AIDS care. J Infect Dis 2007;196(suppl 3):S464-8.

32 Stringer JS, Zulu I, Levy J, Stringer EM, Mwango A, Chi BH, et al. Rapid scale-up of antiretroviral therapy at primary care sites in Zambia: feasibility and early outcomes. JAMA 2006;296:782-93

33 Wools-Kaloustian K, Kimaiyo S, Diero L, Siika A, Sidle J, Yiannoutsos CT, et al. Viability and effectiveness of large-scale HIV treatment initiatives in sub-Saharan Africa: experience from western Kenya. Aids 2006:20:41-8.

34 Rosen S, Fox MP, Gill CJ. Patient retention in antiretroviral therapy programs in sub-Saharan Africa: a systematic review. PLoS Med 2007;4:e298.

35 Brigido L, Rodrigues R, Casseb J, Custodio RM, Fonseca LA, Sanchez M, et al. CD4+ T-cell recovery and clinical outcome in HIV-1-infected patients exposed to multiple antiretroviral regimens: partial control of viremia is associated with favorable outcome. AIDS Patient Care STDS 2004:18:189-98.

36 Lohse N, Kronborg G, Gerstoft J, Larsen CS, Pedersen G, Pedersen C, et al. Virologica control during the first 6-18 months after initiating highly active antiretroviral therapy as a predictor for outcome in HIV-infected patients: a Danish, population-based, 6-yea follow-up study. Clin Infect Dis 2006;42:136-44

37 Weidle PJ, Malamba S, Mwebaze R, Sozi C, Rukundo G, Downing R, et al. Assessment of a pilot antiretroviral drug therapy programme in Uganda: patients' response, survival, and drug resistance. Lancet 2002;360:34-40.

38 Braitstein P, Brinkhof MW, Dabis F, Schechter M, Boulle A, Miotti P, et al. Mortality of HIV-1-infected patients in the first year of antiretroviral therapy: comparison between low-income and high-income countries. Lancet 2006;367:817-24.

39 Sungkanuparph S, Manosuthi W, Kiertiburanakul S, Piyavong B, Chumpathat N, Chantratita W. Options for a second-line antiretroviral regimen for HIV type 1-infected patients whose initial regimen of a fixed-dose combination of stavudine, lamivudine, and nevirapine fails. Clin Infect Dis 2007:44:447-52.

40 DART Virology Group and Trial Team. Virological response to a triple nucleoside/nucleotide analogue regimen over 48 weeks in HIV-1-infected adults in Africa. AIDS 2006;20:1391-9.

41 Reynolds SJ, Kityo C, Mbamanya F, Ndyanabo A, Galiwongo R, Boaz I, et al. Evolution of drug resistance after virological failure of a first-line highly active antiretroviral therapy regimen in Uganda. Antivir Ther 2009;14:293-7.

42 Hoffmann CJ, Charalambous S, Sim J, Ledwaba J, Schwikkard G, Chaisson RE, et al. Viremia, resuppression, and time to resistance in human immunodeficiency virus (HIV) subtype $\mathrm{C}$ during first-line antiretroviral therapy in South Africa. Clin Infect Dis 2009;49:1928-35.

43 Kahn JG, Marseille E, Moore D, Bunnell R, Were W, Degerman R, et al. CD4 cell count and viral load monitoring of antiretroviral therapy in Uganda: cost effectiveness study. BMJ 2011;343:d6884.

44 Chen SC, Yu JK, Harries AD, Bong CN, Kolola-Dzimadzi R, Tok TS, et al. Increased mortality of male adults with AIDS related to poor compliance to antiretroviral therapy in Malawi. Trop Med Int Health 2008;13:513-9.

45 Thompson MA, Aberg JA, Cahn P, Montaner JS, Rizzardini G, Telenti A, et al. Antiretroviral treatment of adult HIV infection: 2010 recommendations of the International AIDS Society-USA panel. JAMA 2010;304:321-33.

46 World Health Organization. Towards universal access: scaling up priority HIV/AIDS interventions in the health sector: progress report, June 2008. WHO, UNAIDS, UNICEF, 2008.

\section{Accepted: 21 September 2011}

\section{Cite this as: BMJ 2011:343:d6792}

This is an open-access article distributed under the terms of the Creative Commons Attribution Non-commercial License, which permits use, distribution, and reproduction in any medium, provided the original work is properly cited, the use is non commercial and is otherwise in compliance with the license. See: http://creativecommons.org/licenses/by$\mathrm{nc} / 2.0 /$ and http://creativecommons.org/licenses/by-nc/2.0/legalcode. 


\section{Tables}

Table 1| Baseline characteristics of participants in study monitoring efficacy of ART, Tororo and Busia Districts, Uganda, 2003-7, according to type of monitoring: viral load arm (clinical monitoring, CD4 cell count, viral load monitoring), CD4 arm (clinical monitoring, CD4 cell count), and clinical arm (clinical monitoring only). Figures are numbers (percentage) of patients unless stated otherwise

\begin{tabular}{|c|c|c|c|c|}
\hline & Viral load arm (n=368) & CD4 arm $(n=371)$ & Clinical arm $(n=377)$ & P value $^{*}$ \\
\hline Median (IQR) age (years) & $37(32-43.5)$ & $38(32-44)$ & $39(32-44)$ & 0.96 \\
\hline Female (\%) & 75 & 75 & 67 & 0.01 \\
\hline \multicolumn{5}{|l|}{ CD4 cell count in cells $\times 10^{6} / \mathrm{L}(\mathrm{IQR}):$} \\
\hline Median & $128(61-194)$ & $127(62-130)$ & $131(70-197)$ & 0.65 \\
\hline$<50$ & $78(21)$ & $76(20)$ & $67(18)$ & - \\
\hline $50-200$ & $209(57)$ & $219(59)$ & $223(59)$ & - \\
\hline$>200$ & $80(22)$ & $76(20)$ & $87(23)$ & - \\
\hline \multicolumn{5}{|l|}{ HIV viral load (copies $/ \mathrm{mL}$ ): } \\
\hline Median (IQR) & $233000(77900-513000)$ & $201000(63600-520000)$ & $210000(74600-570000)$ & 0.63 \\
\hline$<1000$ & $1(0)$ & $3(1)$ & $4(1)$ & - \\
\hline 1000-9999 & $16(4)$ & $11(3)$ & $15(4)$ & - \\
\hline $10000-99999$ & $97(26)$ & $115(31)$ & $95(25)$ & - \\
\hline$\geq 100000$ & $253(69)$ & $242(65)$ & $263(70)$ & - \\
\hline Mean $\log _{10}$ copies $/ \mathrm{mL}$ & 5.2 & 5.2 & 5.2 & 0.84 \\
\hline \multicolumn{5}{|l|}{ Body mass index: } \\
\hline Median (IQR) & $19.7(18-21.5)$ & $19.7(18.1-21.5)$ & $19.6(18.0-21.5)$ & 0.98 \\
\hline$<18.5$ & $111(30)$ & $113(30)$ & $114(30)$ & \\
\hline $18.5-24.9$ & $218(59)$ & $228(61)$ & $238(63)$ & \\
\hline $25-29.9$ & $20(5)$ & $14(4)$ & $12(3)$ & \\
\hline$\geq 30$ & $3(1)$ & $4(1)$ & $3(1)$ & \\
\hline Missing & $16(4)$ & $12(3)$ & $10(3)$ & \\
\hline Median haemoglobin $(\mathrm{g} / \mathrm{L})$ & 112 & 112 & 112 & 0.96 \\
\hline Aspartate aminotransferase (AST) $>1.5$ times normal $(\%)$ & $31(8)$ & $33(9)$ & $32(8)$ & 0.55 \\
\hline Alanine aminotransferase (ALT) >1.5 times normal (\%) & $9(2)$ & $9(2)$ & $16(4)$ & 0.28 \\
\hline Creatinine $>132.6 \mu \mathrm{mol} / \mathrm{L})(\%)$ & $6(2)$ & $11(3)$ & $10(3)$ & 0.38 \\
\hline \multicolumn{5}{|l|}{ Highest level of education completed: } \\
\hline None & $198(54)$ & $205(55)$ & $182(48)$ & 0.48 \\
\hline Primary & $80(22)$ & $70(19)$ & $82(22)$ & \\
\hline More than primary & $80(22)$ & $83(22)$ & $98(26)$ & \\
\hline Missing & $10(3)$ & $13(4)$ & $15(4)$ & \\
\hline \multicolumn{5}{|l|}{ Marital status: } \\
\hline Single & $15(4)$ & $16(4)$ & $17(5)$ & 0.46 \\
\hline Married/cohabiting & $142(39)$ & $127(34)$ & $149(40)$ & \\
\hline Separated/divorced & $31(8)$ & $49(13)$ & $42(11)$ & \\
\hline Widowed & $170(46)$ & $166(45)$ & $154(41)$ & \\
\hline Missing & $10(3)$ & $13(4)$ & $15(4)$ & \\
\hline Received ART for PMTCT in past (women only) & $5(2)$ & $3(1)$ & $4(2)$ & 0.77 \\
\hline In per protocol analysis & $349(95)$ & $346(93)$ & $352(93)$ & 0.61 \\
\hline
\end{tabular}

IQR=interquartile range; PMTCT=preventing mother to child transmission.

${ }^{*}$ Kruskal-Wallis test for continuous variables or $\chi^{2}$ or Fisher's exact test for categorical variables. 
Table 2| Cox proportional hazard models comparing time to first serious morbidity or death, in study monitoring efficacy of ART, Tororo and Busia Districts, Uganda, 2003-7

\begin{tabular}{|c|c|c|c|c|c|c|c|}
\hline & \multirow[b]{3}{*}{ Events/participants } & \multirow[b]{3}{*}{$\begin{array}{l}\text { Person-years } \\
\text { of follow-up }\end{array}$} & \multirow{3}{*}{$\begin{array}{c}\text { Rate per } \\
100 \\
\text { person } \\
\text { years }\end{array}$} & \multicolumn{4}{|c|}{ Hazard ratio $(95 \% \mathrm{Cl}) ; \mathrm{P}$ value } \\
\hline & & & & \multicolumn{2}{|c|}{ Unadjusted } & \multicolumn{2}{|c|}{ Adjusted* } \\
\hline & & & & $\begin{array}{l}\text { Compared with viral } \\
\text { load arm }\end{array}$ & $\begin{array}{l}\text { Compared with } \\
\text { CD4 arm }\end{array}$ & $\begin{array}{l}\text { Compared with viral } \\
\text { load arm }\end{array}$ & $\begin{array}{l}\text { Compared with } \\
\text { CD4 arm }\end{array}$ \\
\hline \multicolumn{8}{|c|}{ Severe morbidity and mortality } \\
\hline \multicolumn{8}{|c|}{ Intention to treat†: } \\
\hline Viral load arm & $47 / 368$ & 979.4 & 4.8 & - & - & - & - \\
\hline CD4 arm & $58 / 371$ & 971.6 & 6.0 & $\begin{array}{c}1.24(0.85 \text { to } 1.83) \\
0.269\end{array}$ & - & $\begin{array}{c}1.23(0.82 \text { to } 1.84) \\
0.309\end{array}$ & - \\
\hline Clinical arm & $72 / 377$ & 950.9 & 7.6 & $\begin{array}{c}1.54 \text { (1.06 to } 2.22) ; \\
0.022\end{array}$ & $\begin{array}{l}1.24(0.88 \text { to } \\
1.75) ; 0.227\end{array}$ & $\begin{array}{c}1.83(1.25 \text { to } 2.69) ; \\
0.002\end{array}$ & $\begin{array}{l}1.49(1.03 \text { to } \\
2.13) ; 0.032\end{array}$ \\
\hline \multicolumn{8}{|c|}{ Per protocol analysisł: } \\
\hline Viral load arm & $24 / 349$ & 884.4 & 2.7 & - & - & - & - \\
\hline CD4 arm & $29 / 346$ & 877.8 & 3.3 & $\begin{array}{c}1.22(0.71 \text { to } 2.10) ; \\
0.466\end{array}$ & - & $\begin{array}{c}1.32(0.76 \text { to } 2.31) \\
0.323\end{array}$ & - \\
\hline Clinical arm & $47 / 352$ & 852.3 & 5.5 & $\begin{array}{c}2.01 \text { (1.23 to } 3.29) ; \\
0.005\end{array}$ & $\begin{array}{l}1.64(1.03 \text { to } \\
2.61) ; 0.035\end{array}$ & $\begin{array}{c}2.31(1.38 \text { to } 3.84) ; \\
0.001\end{array}$ & $\begin{array}{l}1.74(1.09 \text { to } \\
2.79) ; 0.021\end{array}$ \\
\hline \multicolumn{8}{|c|}{ All cause mortality } \\
\hline \multicolumn{8}{|c|}{ Intention to treat $\uparrow:$} \\
\hline Viral load arm & $37 / 368$ & 1002.6 & 3.7 & - & - & - & - \\
\hline CD4 arm & $40 / 371$ & 1008.7 & 4.0 & $\begin{array}{c}1.08(0.69 \text { to } 1.69) ; \\
0.738\end{array}$ & - & $\begin{array}{c}1.10(0.69 \text { to } 1.75) ; \\
0.698\end{array}$ & - \\
\hline Clinical arm & $49 / 377$ & 1003.4 & 4.9 & $\begin{array}{c}1.31(0.85 \text { to } 2.01) ; \\
0.217\end{array}$ & $\begin{array}{l}1.21(0.80 \text { to } \\
1.84) ; 0.366\end{array}$ & $\begin{array}{c}1.57(1.00 \text { to } 2.46) ; \\
0.049\end{array}$ & $\begin{array}{l}1.43(0.92 \text { to } \\
2.21) ; 0.109\end{array}$ \\
\hline \multicolumn{8}{|c|}{ Per protocol analysis $\ddagger$ : } \\
\hline Viral load arm & $20 / 349$ & 891.9 & 2.2 & - & - & - & - \\
\hline CD4 arm & $18 / 346$ & 897.8 & 2.0 & $\begin{array}{c}0.90(0.48 \text { to } 1.70) \\
0.744\end{array}$ & - & $\begin{array}{c}1.00(0.52 \text { to } 1.92) \\
0.99\end{array}$ & - \\
\hline Clinical arm & $28 / 352$ & 890.1 & 3.1 & $\begin{array}{c}1.40 \text { (0.79 to } 2.48) \\
0.255\end{array}$ & $\begin{array}{l}1.55(0.86 \text { to } \\
2.80) ; 0.146\end{array}$ & $\begin{array}{c}1.63(0.90 \text { to } 2.98) \\
0.109\end{array}$ & $\begin{array}{l}1.63(0.89 \text { to } \\
2.99) ; 0.110\end{array}$ \\
\hline
\end{tabular}

*Adjusted for age, sex, baseline CD4 cell count, baseline viral load, and baseline BMI.

†Includes all randomised participants, irrespective of whether they had started ART.

łIncludes only those participants who survived beyond first 90 days of receipt of ART and includes only events that occurred after this point. 
Table 3| Poisson regression models comparing number of events, in study monitoring efficacy of ART, Tororo and Busia Districts, Uganda, 2003-2007. Intention to treat analysis unless otherwise specified

\begin{tabular}{|c|c|c|c|c|c|c|c|}
\hline & \multirow[b]{3}{*}{ Episodes/participants } & \multirow[b]{3}{*}{$\begin{array}{l}\text { Person-years } \\
\text { of follow-up }\end{array}$} & \multirow{3}{*}{$\begin{array}{c}\text { Rate per } \\
100 \\
\text { person } \\
\text { years }\end{array}$} & \multicolumn{4}{|c|}{ Incidence ratio $(95 \% \mathrm{Cl}) ; \mathrm{P}$ value } \\
\hline & & & & \multicolumn{2}{|c|}{ Unadjusted } & \multicolumn{2}{|c|}{ Adjusted $^{*}$} \\
\hline & & & & $\begin{array}{l}\text { Compared with viral } \\
\text { load arm }\end{array}$ & $\begin{array}{l}\text { Compared with } \\
\text { CD4 arm }\end{array}$ & $\begin{array}{l}\text { Compared with viral } \\
\text { load arm }\end{array}$ & $\begin{array}{l}\text { Compared with } \\
\text { CD4 arm }\end{array}$ \\
\hline \multicolumn{8}{|c|}{ New CDC category C illnesses } \\
\hline Viral load arm & $33 / 368$ & 1002.6 & 3.3 & - & - & - & - \\
\hline CD4 arm & $46 / 371$ & 1008.7 & 4.6 & $\begin{array}{c}1.39 \text { (0.89 to } 2.17) \\
0.153\end{array}$ & - & $\begin{array}{c}1.62(0.83 \text { to } 3.15) ; \\
0.158\end{array}$ & - \\
\hline Clinical arm & $67 / 377$ & 1003.4 & 6.7 & $\begin{array}{c}2.03(1.34 \text { to } 3.08) ; \\
0.001\end{array}$ & $\begin{array}{l}1.46(1.01 \text { to } \\
2.13) ; 0.046\end{array}$ & $\begin{array}{c}3.37 \text { (1.84 to } 6.14) \\
<0.0001\end{array}$ & $\begin{array}{l}2.08(1.25 \text { to } \\
3.46) ; 0.005\end{array}$ \\
\hline \multicolumn{8}{|c|}{ New CDC category C illnesses (per protocol analysis) } \\
\hline Viral load arm & $15 / 349$ & 891.9 & 1.7 & - & - & - & - \\
\hline CD4 arm & $23 / 346$ & 897.8 & 2.6 & $\begin{array}{c}1.52 \text { (0.79 to } 2.92) ; \\
0.205\end{array}$ & - & $\begin{array}{c}1.34(0.84 \text { to } 2.15) ; \\
0.222\end{array}$ & - \\
\hline Clinical arm & $46 / 352$ & 890.1 & 5.2 & $\begin{array}{c}3.07 \text { (1.72 to } 5.50) ; \\
0.0002\end{array}$ & $\begin{array}{l}2.02(1.22 \text { to } \\
3.33) ; 0.006\end{array}$ & $\begin{array}{c}2.47 \text { (1.60 to } 3.82) \\
<0.0001\end{array}$ & $\begin{array}{l}1.84(1.24 \text { to } \\
2.73) ; 0.002\end{array}$ \\
\hline \multicolumn{8}{|l|}{ Tuberculosis } \\
\hline Viral load arm & $29 / 368$ & 1002.6 & 2.9 & - & - & - & - \\
\hline CD4 arm & $27 / 371$ & 1008.7 & 2.7 & $\begin{array}{c}0.93(0.55 \text { to } 1.56) \\
0.772\end{array}$ & - & $\begin{array}{c}0.92(0.53 \text { to } 1.61) \\
0.783\end{array}$ & - \\
\hline Clinical arm & $37 / 377$ & 1003.4 & 3.7 & $\begin{array}{c}1.27(0.78 \text { to } 2.07) ; \\
0.328\end{array}$ & $\begin{array}{l}1.38(0.84 \text { to } \\
2.26) ; 0.206\end{array}$ & $\begin{array}{c}1.56(0.94 \text { to } 2.60) \\
0.084\end{array}$ & $\begin{array}{l}1.69(1.01 \text { to } \\
2.85) ; 0.047\end{array}$ \\
\hline \multicolumn{8}{|c|}{ Extrapulmonary tuberculosis } \\
\hline Viral load arm & $3 / 368$ & 1002.6 & 0.3 & - & - & - & - \\
\hline CD4 arm & $7 / 371$ & 1008.7 & 0.7 & $\begin{array}{c}2.32(0.60 \text { to } 8.97) ; \\
0.223\end{array}$ & - & $\begin{array}{c}3.02(0.61 \text { to } 15.01) \\
0.177\end{array}$ & - \\
\hline Clinical arm & $14 / 377$ & 1003.4 & 1.4 & $\begin{array}{c}4.66(1.34 \text { to } 16.23) \\
0.016\end{array}$ & $\begin{array}{l}2.01(0.81 \text { to } \\
4.98) ; 0.131\end{array}$ & $\begin{array}{c}7.27(1.64 \text { to } 32.30) ; \\
0.009\end{array}$ & $\begin{array}{c}2.41(0.92 \text { to } \\
6.33) ; 0.074\end{array}$ \\
\hline \multicolumn{8}{|c|}{ Cryptococcal infection } \\
\hline Viral load arm & $11 / 368$ & 1002.6 & 1.1 & - & - & - & - \\
\hline CD4 arm & $11 / 371$ & 1008.7 & 1.1 & $\begin{array}{c}0.99(0.43 \text { to } 2.29) \\
0.989\end{array}$ & - & $\begin{array}{c}0.74(0.30 \text { to } 1.84) ; \\
0.516\end{array}$ & - \\
\hline Clinical arm & $22 / 377$ & 1003.4 & 2.2 & $\begin{array}{c}2.00(0.97 \text { to } 4.12) ; \\
0.061\end{array}$ & $\begin{array}{l}2.01(0.97 \text { to } \\
4.15) ; 0.059\end{array}$ & $\begin{array}{c}2.21 \text { (1.06 to } 4.59) ; \\
0.034\end{array}$ & $\begin{array}{l}2.99(1.32 \text { to } \\
6.77) ; 0.009\end{array}$ \\
\hline \multicolumn{8}{|c|}{ Kaposi's sarcoma } \\
\hline Viral load arm & $4 / 368$ & 1002.6 & 0.4 & - & - & - & - \\
\hline CD4 arm & $7 / 371$ & 1008.7 & 0.7 & $\begin{array}{c}1.74(0.51 \text { to } 5.94) ; \\
0.377\end{array}$ & - & $\begin{array}{c}1.50(0.42 \text { to } 5.35) ; \\
0.528\end{array}$ & - \\
\hline Clinical arm & $11 / 377$ & 1003.4 & 1.1 & $\begin{array}{c}2.75(0.87 \text { to } 8.63) ; \\
0.083\end{array}$ & $\begin{array}{l}1.58(0.61 \text { to } \\
4.08) ; 0.344\end{array}$ & $\begin{array}{c}2.75(0.87 \text { to } 8.70) ; \\
0.084\end{array}$ & $\begin{array}{l}1.83(0.67 \text { to } \\
5.01) ; 0.239\end{array}$ \\
\hline \multicolumn{8}{|c|}{ Pneumocystis jirovecii pneumonia } \\
\hline Viral load arm & $2 / 368$ & 1002.6 & 0.2 & - & - & - & - \\
\hline CD4 arm & $1 / 371$ & 1008.7 & 0.1 & $\begin{array}{c}0.50(0.05 \text { to } 5.48) \\
0.568\end{array}$ & - & $\begin{array}{c}0.58(0.05 \text { to } 6.46) \\
0.659\end{array}$ & - \\
\hline Clinical arm & $11 / 377$ & 1003.4 & 1.1 & $\begin{array}{c}5.50(1.22 \text { to } 24.79) \\
0.027\end{array}$ & $\begin{array}{c}11.06(1.43 \text { to } \\
85.7) ; 0.021\end{array}$ & $\begin{array}{c}9.57(1.96 \text { to } 46.71) \\
0.005\end{array}$ & $\begin{array}{l}16.5(2.04 \text { to } \\
132.6) ; 0.009\end{array}$ \\
\hline
\end{tabular}

*Adjusted for age, sex, baseline CD4 cell count, baseline viral load, and BMI. 
Table 4| Viral load response and switch to second line regimens in study monitoring efficacy of ART, Tororo and Busia Districts, Uganda, 2003-7. Figures are numbers (percentages where shown)

\begin{tabular}{|c|c|c|c|c|}
\hline & $\begin{array}{c}\geq 2 \text { viral loads }>500 \text { copies } / \mathrm{mL} \text { after } 90 \\
\text { days }\end{array}$ & $\begin{array}{l}\text { Proportion changed to second } \\
\text { line }\end{array}$ & Total changed to second line & $\begin{array}{l}\text { Changed to second line with } \\
\text { detectable viral load }\end{array}$ \\
\hline Viral load & $16 / 349(4.6)$ & $7 / 16(44)$ & 7 & $7 / 7(100)$ \\
\hline CD4 & $26 / 346(7.5)$ & $4 / 26(15)$ & 4 & $4 / 4(100)$ \\
\hline Clinical & $19 / 352(5.4)$ & 2/19 (11) & 17 & 2/17 (12) \\
\hline All & $61 / 1047(5.5)$ & $13 / 61(21)$ & 28/1047 (2.8) & $13 / 28(46)$ \\
\hline
\end{tabular}




\section{Figures}

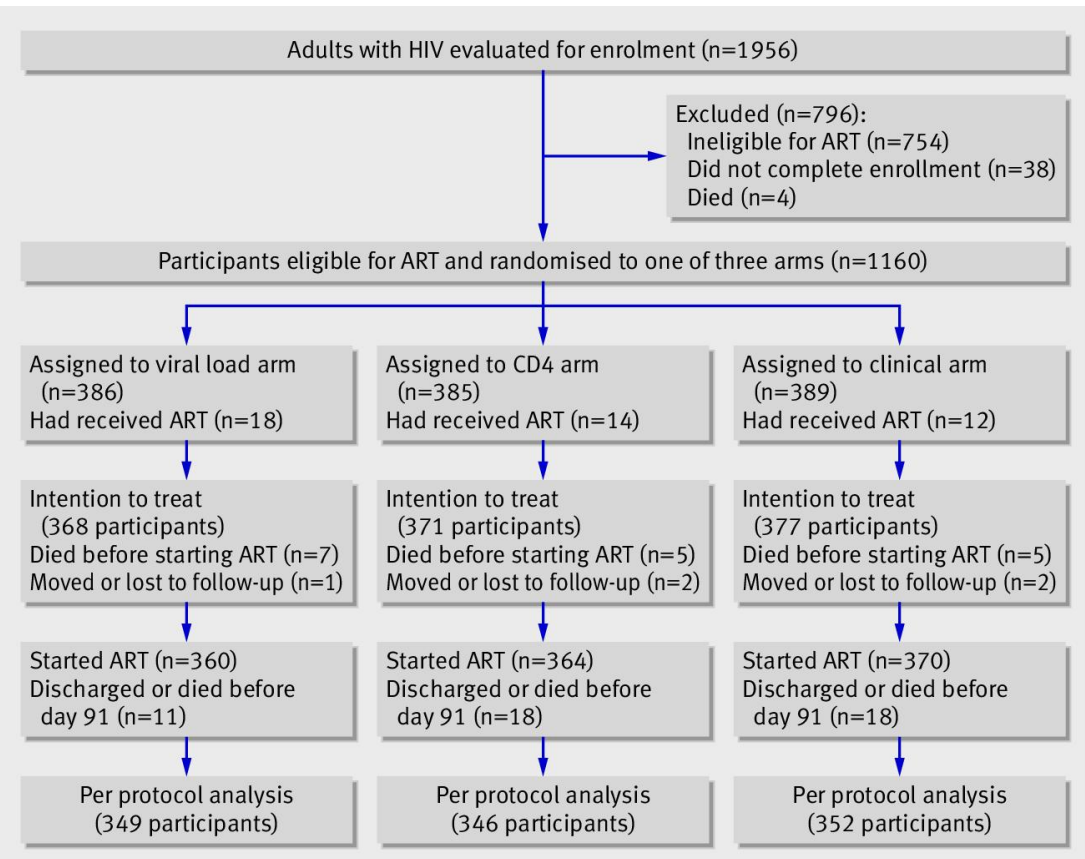

Fig 1 Trial profile of participants with HIV enrolled and followed up in study monitoring efficacy of ART, Tororo and Busia Districts, Uganda, 2003-7

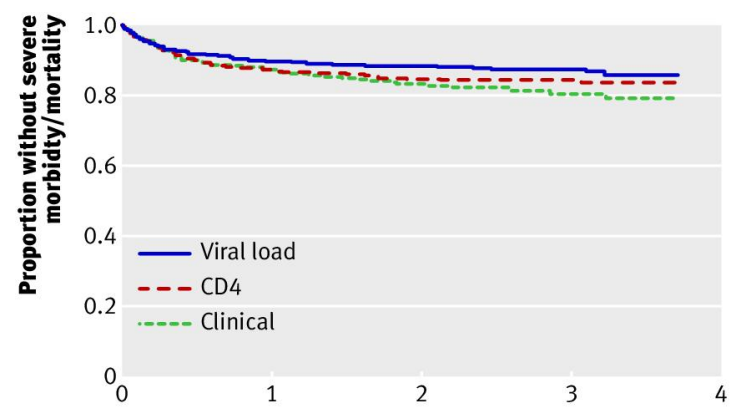

Time (years) to first serious morbidity/mortality

Fig 2 Time to first event of severe morbidity or mortality, intention to treat analysis, Tororo and Busia Districts, Uganda, 2003-7 (log rank $\mathrm{P}=0.067$ ). $\mathrm{P}=0.02$ for viral load $v$ clinical, $\mathrm{P}=0.22$ for $\mathrm{CD} 4 v$ clinical, $\mathrm{P}=0.26$ for viral load $v$ CD4

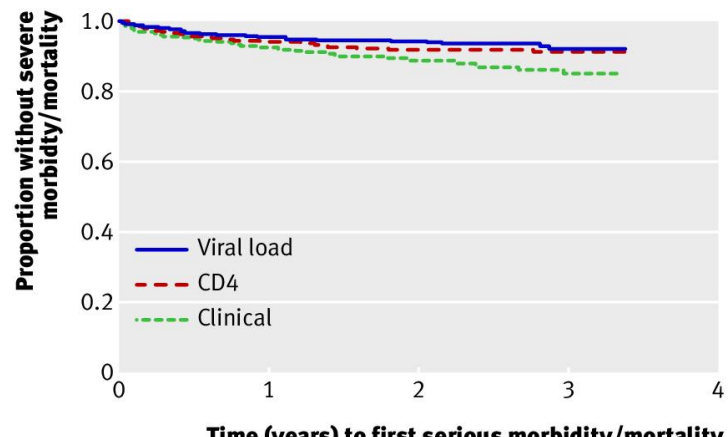

Fig 3 Time to first severe morbidity event or death, per protocol analysis excluding first 90 days of ART, Tororo and Busia Districts, Uganda, 2003-7 (log rank $\mathrm{P}<0.009$ ). $\mathrm{P}=0.004$ for viral load $v$ clinical, $\mathrm{P}=0.034$ for $\mathrm{CD} 4 v$ clinical, $\mathrm{P}=0.46$ for viral load $v$ CD 4 